\title{
Fatty acid composition of Achene oils from five Moroccan climatic cultivars of Cannabis
}

\author{
By A. Merzouki and J. Molero Mesa
}

Departamento de Biología Vegetal, Facultad de Farmacia, Campus de Cartuja. 18071 Granada. España

\begin{abstract}
RESUMEN
Composición en ácidos grasos del aceite de los aquenios de cinco variedades climáticas marroquíes de Cannabis.

Se estudia la composición en ácidos grasos del aceite de los aquenios de cinco variedades climáticas del cáñamo (Cannabis sativa L) cultivadas en el norte de Marruecos. Predomina el ácido linoleico ( 40 a $45 \%$ ) seguido por el linolénico (12 a $17 \%$ ) y el oleico (7 a 10\%). Las diferencias en la composición de los ácidos grasos del aceite se atribuyen a factores ambientales.
\end{abstract}

PALABRAS-CLAVE: Acido graso (composición) - Aquenio Cannabis - Marruecos.

\section{SUMMARY}

Fatty acid composition of Achene oils from five Moroccan climatic cultivars of Cannabis.

The fatty acid composition of achene oil from five Cannabis climatic cultivars cultivated in the nort of Morrocco is determined. Linoleic acid predominated ( 40 to $45 \%$ ), followed by linolenic ( 12 to $17 \%$ ) and oleic ( 7 to $10 \%$ ) acids. Differences in the fatty acid composition of oils are attributed to environmental factors.

KEY-WORDS: Achene - Cannabis - Fatty acid (composition) - Morocco.

\section{INTRODUCTION}

Hemp (Cannabis sativa L.) an herbaceous annual plant is of economic importance as a drug, a fibre and oil seed plant. It's considered as one of the oldest of cultivated plants and appears to have originated in northern China (Hui Lin Li, 1974), where it grew in the wild state still around 5200 to 6200 years ago. Actually hemp spread throughout most of the temperature and tropic regions of the world.

Both genetic and environmental conditions influenced the biosynthesis process in hemp plant, essentially cannabinoids composition. Warm, dry and windy conditions were believed to induce a higher density of resin glands where the biosynthesis of cannabinoids takes place (Crombie, 1977; Valle et al., 1978; Braut-Boucher, 1980; Mahlberg and Hemphill, 1983). Murari et al., (1983), estimated higher contents of cannabinoids, in the same varieties, when hemp grown in a continental climate than in a maritime climate.

One of many compounds secondary metabolites produced by hemp is oil, resulting from the plant lipid synthesis and achenes are the primary storage tissue for accumulating oil. Achenes of Cannabis contain around $30-35 \%$ oil, which is brownish-green in colour and smells of the seed (Vaughan, 1970). The oil possesses marked drying properties, and it's used in the manufacture of paint, soaps, varnishes, printing inks and an edible oil. Many countries cultivate hemp as an oil-seed plant, like Manchuria, Chile, Turkey, China, Formosa, Hungary, Czechoslovakia and Francia, the main world cultivator is the ancient USSR. The average annual production of seed being in the region was 250.000 tons (Altschul cited in Vaughan, 1970).

In previous studies (Merzouki and Molero Mesa, 1995; Merzouki et al., 1996a and b) about Cannabis chimiotaxonomy (seed morphology and cannabinoids composition), we have concluded that Cannabis cultivated in the Rif belongs to the drug phenotype and the genus was monotype (Cannabis sativa L.).

The Rif, space of Cannabis cultivation in Morocco, is characterized by a high ecological variety where bioclimates vary from arid to perhumid (Ben Abid, 1982).

The purpose of this study was to determine oil concentrations and differences in the fatty acid composition of the oil in achene from the five "Cannabis climatic varieties" cultivated in the north of Morocco.

\section{MATERIAL AND METHODS}

When ripe, achenes of Cannabis were collected from different localities of the Rif (North of Morocco), 
1-Ketama, 2-Jebha, 3-Bouhmed, 4-Chaouen and 5Bad Taza. In each locality, 5 Cannabis populations are selected. From achenes of each population, one sample was prepared.

Achene samples were milled and the oil was extracted $n$-hexane in a Soxhlet apparatus. The extract was dried over anhydrous sodium sulphate and the solvent removed under reduced pressure in a rotary film evaporator. Fatty acid composition of solvent-extracted oils from achenes was determined using transesterification of the triacylglycerols with a solution $0,5 \mathrm{~N} \mathrm{KOH}$ in methanol (Sonanini and Weber in LawiBerger, 1982) and the methyl esters analysed by gas chromatography uing a glass column $(20 \mathrm{~m}$ long and $2.25 \mathrm{~mm}$ ID) coated with SP-2330. The detector was a flame ionization detector. A fatty acid standard containing the fatty acids myristic (C:14), palmitic (C16:0), stearic (C18:0), oleic (C18:1), linoleic (C18:2), linolenic (C18:3), arachidic (C20), behenic (C22:0), lignoceric (C24:0). Fatty acid peaks were identified by comparing the fatty acid methyl ester peaks and retention times of standards with sample peaks. Standard solution of margaric acid methyl ester was used for quantification. Seed oil and fatty acid concentrations were determined from one sample per population (Five samples per locality). Means and standard deviation of means are presented to give some ideas of the variability of oil and fatty acids within each variety. Variance analyse (ANOVA) was used to compare oil and fatty acid concentrations between varieties. Correlation analyses were used to examine the relationships among fatty acid composition and ecological and geographical parameters $\left[\mathrm{T}^{\circ} \operatorname{Max} .\left({ }^{\circ} \mathrm{C}\right), \mathrm{T}^{\circ}\right.$ $\min .\left({ }^{\circ} \mathrm{C}\right)$, precipitation $(\mathrm{mm})$, altitude $(\mathrm{m})$, latitude and longitude].

\section{RESULTS AND DISCUSSION}

Oil concentrations of 5 «climatic Cannabis varieties» from the Rif are summarized in Table I.

Table I

Means and standard deviation (SD) of seed oil concentration (\%) from five Rifian Cannabis varieties

\begin{tabular}{llll}
\hline Variétés & N & Mean & S.D. \\
\hline Kétama & 5 & 33.84 & 1.29 \\
Jebha & 5 & 33.72 & 1.62 \\
Bouhmed & 5 & 30.96 & 1.29 \\
Chaouen & 5 & 34.60 & 1.28 \\
Bad Taza & 5 & 32.48 & 0.91 \\
\hline
\end{tabular}

$\mathrm{N}=$ number of samples
Values varied from $30.96 \%$ to $34.60 \%$. The highest mean oil concentration was observed in Cannabis seeds from Chaouen and the lowest mean was observed in Bouhmed locality.

Difference analysis between mean oil concentrations of each locality (variance analysis) was consigned in Table II, and reveal that seed oil concentration from Bouhmed locality vary significantly with seed oil concentrations of Kétama, Jebha, Chaouen localities at $P=0.01$, and vary significantly at $\mathrm{P}=0.05$ with this from Bab Taza.

Table II

Significant difference at $95 \%$ and $99 \%$ confidence for mean between seed oil concentrations from five Rifian Cannabis localities

\begin{tabular}{lccccc}
\hline & Ketama & Jebha & Bouhmed & Chaouen BabTaza \\
\hline Ketama & 1 & & & & \\
Jebha & NS & 1 & & & \\
Bouhmed & $* \star$ & $* \star$ & 1 & & \\
Chaouen & NS & NS & $* *$ & 1 & 1 \\
Bab Taza & NS & NS & $*$ & $* *$ & 1 \\
\hline
\end{tabular}

$* \quad$ Significant difference at $P=0.05$
Significant difference at $P=0.01$

NS Non significant difference

The fatty acid composition from Cannabis achenes is summarized in Table III and Fig. 1. The major fatty acids observed were C18:1, C18:2 and C18:3 in each variety. The lowest one is $\mathrm{C} 24$ which varied from 0.31 in Ketama to $0.76 \mu \mathrm{Mol} / \mathrm{g}$ oil in Chaouen. Results of variance analysis were summarized in Table IV. Difference analysis of each fatty acid between localities reveal that fatty acid concentrations from Bouhmed achene variety presents a clear difference with the other varieties. The myristic, palmitic, oleic, linoleic, behenic and lignoceric acids from Bouhmed achene variety are a highly significant difference to the others varieties. Achene oil from Bab Taza location are characterized by 3 fatty acids, oleic (C18:1), linoleic (C18:2) and arachidic (C20). These fatty acids are significantly different to thus from others localities.

Seiler (1986) concluded that environmental factors, especially temperature, during the period of achene development and maturation affect both the concentration and composition of oil in maturing sunflower achenes. Therefore, differences in fatty acid composition found in Cannabis achene oils can be attributed to environmental factors.

Results of Rifian Cannabis varieties show that the achene oils have similar fatty acid composition than the varieties analysed by Lawi-Berger (1982), who has compared fibre and drug varieties. In such study, the author reveal that comparison of fatty acid 
Table III

Fatty acid concentrations ( $\mu \mathrm{Mol} / 1 \mathrm{~g}$ achene oil) and ecological, and geographical factors of 5 Cannabis climatic varieties from Morocco

\begin{tabular}{|c|c|c|c|c|c|}
\hline \multicolumn{6}{|c|}{ Localities } \\
\hline & Ketama & Jebha & Bouhmed & Chaouen & Bab Taza \\
\hline \multicolumn{6}{|c|}{ Mean (Standard deviation) } \\
\hline Alt. (m) & $1338-1510$ & $95-270$ & $55-150$ & $342-400$ & $765-880$ \\
\hline$P(\mathrm{~mm})$ & $1504(114.58)$ & $195.6(52.86)$ & $289.2(99.37)$ & $993.20(75.15)$ & $1044(135.11)$ \\
\hline $\operatorname{Tmax}^{\circ} \mathrm{C}$ & $31.3(1.51)$ & $32.06(3.29)$ & $29.5(0.58)$ & $30.80(2.07)$ & $30.8(1.28)$ \\
\hline $\operatorname{Tmin}^{\circ} \mathrm{C}$ & $-0.02(1.21)$ & $4.14(0.73)$ & $7.26(0.74)$ & $3.66(1.07)$ & $3.3(0.67)$ \\
\hline Lat. & $34^{\circ} 48^{\prime}-34^{\circ} 56^{\prime}$ & $35^{\circ} 09^{\prime}-35^{\circ} 11^{\prime}$ & $34^{\circ} 25^{\prime}-32^{\circ} 27^{\prime}$ & $35^{\circ} 11^{\prime}-35^{\circ} 50^{\prime}$ & $35^{\circ} 09^{\prime}-35^{\circ} 15^{\prime}$ \\
\hline Long. & $4^{\circ} 33^{\prime}-4^{\circ} 42^{\prime}$ & $4^{\circ} 32^{\prime}-4^{\circ} 38^{\prime}$ & $4^{\circ} 25^{\prime}-4^{\circ} 55^{\prime}$ & $5^{\circ} 09^{\prime}-5^{\circ} 11^{\prime}$ & $5^{\circ} 07^{\prime}-5^{\circ} 14^{\prime}$ \\
\hline $\mathrm{C} 14$ & $10.64(1.43)$ & $9.46(0.94)$ & $12.80(0.78)$ & $9.92(0.88)$ & $9.04(0.53)$ \\
\hline $\mathrm{C} 16$ & $175.72(7.25)$ & $192.04(6.05)$ & $167.42(12.60)$ & $157.12(11.92)$ & $229.7(17.27)$ \\
\hline C18 & $65.56(2.50)$ & $58.70(2.53)$ & $53.90(7.53)$ & $62.88(3.23)$ & $54.64(3.31)$ \\
\hline C18: 1 & $313.54(7.36)$ & 320.26 (12.94) & $264.14(8.47)$ & $358.36(7.40)$ & 343.26 (11.19) \\
\hline C18: 2 & $1427.94(19.25)$ & $1424.14(57.55)$ & $1227.34(24.58)$ & $1343.76(25.04)$ & $1625.64(18.40)$ \\
\hline C18: 3 & $624.74(11.54)$ & $548.28(3.96)$ & $530.62(67.46)$ & $431.62(7.45)$ & $540.48(17.30)$ \\
\hline C20 & $40.58(3.60)$ & $56.36(3.65)$ & $33.90(2.83)$ & $36.16(2.23)$ & $80.80(6.28)$ \\
\hline $\mathrm{C} 22$ & $4.68(0.37)$ & $5.24(0.67)$ & $3.18(0.78)$ & $4.48(0.67)$ & $5.96(1.33)$ \\
\hline $\mathrm{C} 24$ & $0.50(0.07)$ & $0.66(0.15)$ & $0.31(0.11)$ & $0.52(0.14)$ & $0.76(0.11)$ \\
\hline
\end{tabular}

Alt. $=$ Altitude

$\mathrm{P}=$ Precipitation

Table IV

Difference analysis of means of fatty acid concentrations between all localities

\begin{tabular}{|c|c|c|c|c|c|}
\hline & Kétama & Jebha & Bouhmed & Chaouen & Bab Taza \\
\hline Kétama & - & & & & \\
\hline Jebha & $\begin{array}{l}1^{\text {ns }} 2^{* *} 3^{* *} \\
4^{\text {ns }} 5^{\text {ns }} 6^{* *} \\
7^{* *} 8^{\text {ns }} 9^{\text {ns }}\end{array}$ & - & & & \\
\hline Bouhmed & $\begin{array}{l}1^{* *} 2^{*} 3^{* *} \\
4^{* *} 5^{* *} 6^{*} \\
7^{*} 8^{*} 9^{*}\end{array}$ & $\begin{array}{ll}1^{* *} 2^{* *} & 3^{\text {ns }} \\
4^{* *} & 5^{* *} 6^{\text {ns }} \\
7^{* *} & 8^{* *} 9^{* *}\end{array}$ & - & & \\
\hline Chaouen & $\begin{array}{lll}1^{* *} 2^{* *} & 3^{n s} \\
4^{* *} & 5^{* *} & 6^{* *} \\
7^{*} & 8 \text { ns } & 9^{n s}\end{array}$ & $\begin{array}{l}1^{\text {ns }} 2^{* *} 3^{*} \\
4^{* *} 5^{*} 6^{* *} \\
7^{* *} 8^{\text {ns }} 9^{\text {ns }}\end{array}$ & $\begin{array}{lll}1^{* *} & 2^{* *} & 3^{*} \\
4^{* *} & 5^{* *} & 6^{* *} \\
7 \text { ns } & 8^{*} & 9^{*}\end{array}$ & - & \\
\hline Bab Taza & $\begin{array}{l}1^{*} 2^{*} 3^{* *} \\
4^{* *} 5^{* *} 6^{* *} \\
7^{* *} 8^{\text {ns }} 9^{* *}\end{array}$ & $\begin{array}{l}1^{\text {ns }} 2^{\text {ns }} 3^{\text {ns }} \\
4^{* *} 5^{* *} 6^{\text {ns }} \\
7^{* *} 8^{\text {ns }} 9^{\text {ns }}\end{array}$ & $\begin{array}{l}1^{* *} 2^{* *} 3^{n s} \\
4^{*} 5^{* *} 6^{\text {ns }} \\
7^{* *} 8^{* *} 9^{* *}\end{array}$ & $\begin{array}{l}1^{* *} 2^{* *} 3^{* *} \\
4^{*} 5^{* *} 6^{* *} 7^{*} \\
8 \text { ns } 9^{*}\end{array}$ & - \\
\hline
\end{tabular}

1- C14, 2-C16, 3-C18, 4-C18:1, 5-C18:2, 6-C18:3, 7-C20, 8-C22, 9-C24

* Significant difference at $95 \%$

** Significant difference at $99 \%$

ns:Non significant difference 
concentrations don't permit to distinguish fibre or drug Cannabis variety.

The variability observed in fatty acids of the five Cannabis varieties cultivated in the Rif region was undoubtedly caused by differences in environment at different locations.

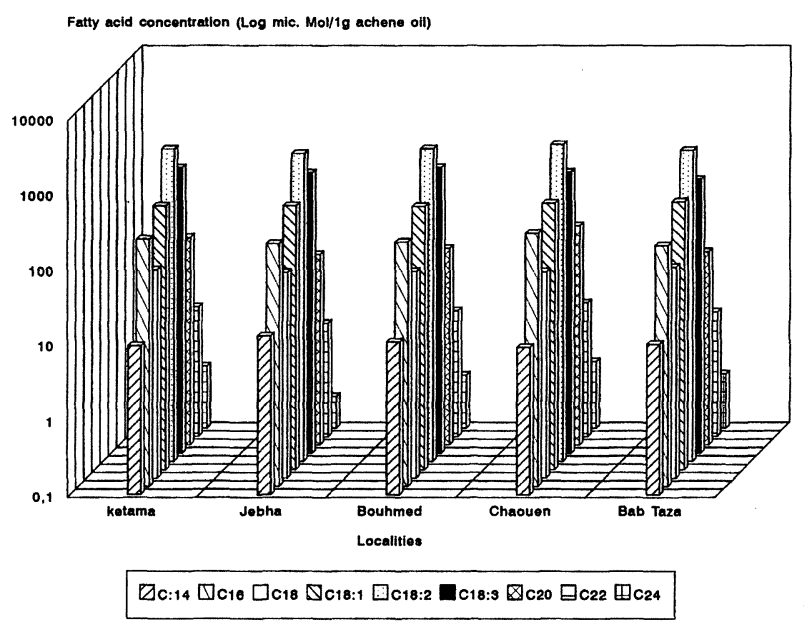

Figure 1

Fatty acid concentrations of 5 Cannabis climatic varieties from Morocco

\section{BIBLIOGRAPHY}

Ben Abid A. (1982) -«Etude phytoécologique, Biogéographique et dyamique des associations et series sylvastiques du Rif occidental (Maroc). Thèse Doctorat es-Sciences, Faculté des Sciences et Techniques".- St. Jerôme, Marseille.

Braut-Boucher, F. (1980). - «Effect des conditions écophisiologiques sur la croissance, le developpement et le contenu en Cannabinoides des classes correspondants aux deux types chimiques du Cannabis Sativa L. originaire d'Afrique du Sud".- Physiol. Veg. 18, 207.

Crombie, W. (1977). - "The influence of photosynthesis and SKF inhibitors on cannabinoid production in Cannabis sativa L».- Phytochemistry 16, 1369.

Hively, R. L. (1966). - «A study of chemistry of marihuana».Ph. D. Thesis. Ann. Arbor. Mich. (Diss. Abstr. 28, 1412B).

Hui Lin Li (1974). - «The origin and use of Cannabis in eastern Asia, Linguistic-Cultural implications»- Econ. Bot. 28 3, 293.

Lawi-Berger, C. (1982). - “Contribution à l'étude chimiotaxonomique du genre Cannabis (Cannabaceae)»- Thèse 2059, Univ. de Genève, 154p.

Mahlberg, P. G. \& Hemphill, J. K. (1983). - «Effect of light quality on cannabinoid content of Cannabis sativa $L$. (Cannabaceae)".- Bot. Gaz. 144 (1) 43.

Merzouki, A. and Molero Mesa, J. (1995). - "Chemical phenotype in Moroccan hemp (Cannabis sativa L.)"- Al Biruniya, Rev. Mar. Pharm. 11 (1) 25.

Merzouki, A., M. Casares Porcel and Molero Mesa, J. (1996). -«Etude morphologique des akènes de quelques «espèces» du genre Cannabis: Approche taxonomique".Arch. Geobot. 21 (1) (In press).

Merzouki, A., M. Casares Porcel and Molero Mesa, J. (1996). - «Etude morphologique des akènes de 4 variétés climatiques du Cannabis du Rif (Nord du Maroc)". ARS Pharm. 37 (2) (In press).

Merzouki, A., Ed-Derfoufi F. \& Molero-Mesa, J. (1994). -«What about Cannabis taxonomy?»- ARS Phar. 35 (2) 289.

Murari, G., Lombardi, S., Puccini, A. M \& De Sanctis, R. (1983). - «Influence of environmental conditions on trahydrocannabinol (delta 9-THC) in different cultivars of Cannabis Sativa L». Fitoterapia 54, 195.

Seiler, G. J. (1986). - «Analysis of the relationships of environmental factors with seed oil and fatty acid concentrations of wild annual sunflower».- Field Crops Research 15, 57.

Valle, J., Viera, J., Eucelio, J. \& Valio, I. (1978). - «Influence of photoperiodism on cannabinoid content of Cannabis sativa L".- Bull. Narcotics 30, 67 .

Vaughan, J. G. (1970). - «The structure and utilization of oil seeds"- Eds. Chapman and Hall LTD. London, 279 p.

Recibido: Noviembre 1996 Aceptado: Marzo 1997 